\title{
Microbiological Analysis of an Active Pilot-Scale Mobile Bioreactor Treating Organic Contaminants
}

by

R. L. Brigmon

Westinghouse Savannah River Company

Savannah River Site

Aiken, South Carolina 29808

DOE Contract No. DE-AC09-96SR18500

This paper was prepared in connection with work done under the above contract number with the U.S. Department of Energy. By acceptance of this paper, the publisher and/or recipient acknowledges the U. S. Government's right to retain a nonexclusive, royalty-free license in and to any copyright covering this paper, along with the right to reproduce and to authorize others to reproduce all or part of the copyrighted paper. 


\section{DISCLAIMER}

This report was prepared as an account of work sponsored by an agency of the United States Government. Neither the United States Government nor any agency thereof, nor any of their employees, makes any warranty, express or implied, or assumes any legal liability or responsibility for the accuracy, completeness, or usefulness of any information, apparatus, product, or process disclosed, or represents that its use would not infringe privately owned rights. Reference herein to any specific commercial product, process, or service by trade name, trademark, manufacturer, or otherwise does not necessarily constitute or imply its endorsement, recommendation, or favoring by the United States Government or any agency thereof. The views and opinions of authors expressed herein do not necessarily state or reflect those of the United States Government or any agency thereof.

This report has been reproduced directly from the best available copy.

Available to DOE and DOE contractors from the Office of Scientific and Technical Information, P. O. Box 62, Oak Ridge, TN 37831; prices available from (423) 576-8401.

Available to the public from the National Technical Information Service, U. S. Department of Commerce, 5285 Port Royal Road, Springfield, VA 22161. 


\section{DISCLAIMER}

Portions of this document may be illegible electronic image products. Images are produced from the best available original document. 
Submitted to:

Southeastern Technology Center

501 Greene Street, Suite 400

Augusta, Georgia 30901

Attention: Dr. Regina S. Porter

Re: STC TASK ORDER 97-003 EVALUATION OF PILOT SCALE

MOBILE BIOREACTOR DEMO

Submitted by:

Dr. Robin L. Brigmon

Environmental Biotechnology Section

Savannah River Technology Center

Westinghouse Savannah River Company

Bldg. 704-8T (TNX)

Aiken, SC 29808

Phone (803) 557-7719 


\section{Introduction}

Samples were obtained for microbiological analysis from a granular activated carbon fluidized bed bioreactor (GAC-FBR). This GAC-FBR was in operation at a former manufactured gas plant (MGP) Site in Augusta Georgia for in situ groundwater bioremediation of organics. The samples included contaminated site groundwater, GACFBR effluent, and biofilm coated granular activated carbon at 5, 9, and 13 feet within the GAC-FBR column. The objective of this analysis was to correlate contaminant removal with microbiological activity within the GAC-FBR.

\section{Microbiological Analysis}

Total bacterial densities were determined by the Acridine Orange $(\mathrm{AO})$ direct count method (Hobbie et al., 1977). Acridine orange binds to nucleic acids with the RNA-AO complex fluorescing orange-red while the DNA-AO complex fluoresces green. The AO method has been used as an indicator of bacteria activity. Bacteria cells prepared this way that are labeled orange-red are considered "active" while those that are labeled green are considered "inactive." This technique stains bacterial RNA and DNA facilitating enumeration by epifluorescent microscopy.

Total viable aerobic bacteria were enumerated using the plate count technique. One percent Peptone-Trypticase-Yeast-extract-Glucose (PTYG) medium was used to culture these bacteria (Balkwill, 1989).

The number of viable aerobic bacteria capable of growth on petroleum as a carbon and energy source were enumerated using a minimal salts growth medium amended with 
petroleum (Rodina, 1972). Petroleum fuel contains benzene, toluene, ethylbenzene, xylenes (BTEX), naphthalene and other organic compounds present in these MGP petroleum-contaminated soils (PCS).

Laser scanning confocal microscopy (LSM) was employed to examine the biofilm that developed on the GAC-FBR as previously described (Brigmon et al., 1997). GAC samples from the GAC-FBR were heat fixed on microscope slides and stained with AO. The samples were then examined with LSM.

\section{Results}

The bacteria densities inside the GAC-FBR were two orders of magnitude higher than the influent and effluent groundwater for AOs and four orders of magnitude higher for viable plate counts (Table 1). The results are expressed as colony forming units (CFU) gram dry weight ${ }^{-1}(\mathrm{gdw})$ for the carbon and CFU per milliliter (ml) for groundwater. The densities of total bacteria, viable bacteria, and petroleum fuel degraders were not significantly different at the three depths within the GAC-FBR column (Table 1). There were no petroleum fuel degraders detected in the effluent or influent water. Bacteria densities in both influent and effluent were several orders of magnitude less than the GACFBR.

While the densities of bacteria were similar in GAC-FBR at the three depths, different morphological characteristics in the GAC-FBR matrix were observed. Figure 1 from the 5 foot depth shows a diverse biofilm with filamentous bacteria. Many protozoans were present in this sample (i.e. large round organisms). Protozoans graze on bacteria. Figure 2 demonstrates a similar biofilm at 9 feet with fewer filamentous bacteria and very few protozoa. At the 13 foot depth of the GAC-FBR primarily bacterial rods were observed (Figure 3). A large percentage of the bacteria stained orange-red relative those 
staining green with $\mathrm{AO}$ in the 13 foot sample indicating a high level of microbial activity (Figure 3). Total bacteria densities from the GAC-FBR samples were comparable to the number of viable aerobic bacteria. Effluent and influent samples plate counts or viable bacteria were two orders of magnitude lower compared to total counts (Table 1). The lower viablity in the influent could be due to site groundwater conditions. The lower viablity in the effluent could be due to dead or inactive cells sloughing off the biofilm.

\section{Conclusion}

The objective of this analysis was to correlate microbiological activity within the GAC-FBR with contaminant removal. Evidence that the process was working included GAC-FBR inlet and outlet concentrations for BTEX and Naphthalene demonstrating successful elimination of these compounds (Haselow, 1997). The microbiological analysis proved the presence of an active biofilm within the GAC-FBR and most importantly the high density of petroleum degraders within the system. The evidence of organic contaminant removal by the GAC-FBR and concomitant presence of specific microbiological activity on GAC suggests contaminant removal is a function of biodegradation. Microbial activity was likely influenced by compounds within the GACFBR since the influent groundwater had organic contaminants as well as additional oxygen, phosphate and nitrogen amendments not discussed here.

Note: This work was the result of sampling the GAC-FBR at one time point during operation. In light of these findings an additional short term study is recommended. This new study would determine the most efficient strategy for operation of the GAC-FBR. The questions to be answered would be: 1) what is the influence on the GAC biofilm of flow and or concentration change through the FBR, and 2) what is the stability of the biofilm and biodegradation rates? 
This Page Intentionally Left Blank. 


\section{References}

Balkwill, D. L. 1989. Numbers, diversity, and morphological characteristics of aerobic, chemoheterotrophic bacteria in deep subsurface sediments from a site in South Carolina. Geomicrobiol. J. 7:33-52.

Brigmon, R.L., Martin H. W., and Aldrich, H.C. 1997. Biofouling of Groundwater Systems by Thiothrix spp. Curr. Microbiol. 35:169-174.

Haselow, J. 1997. Preliminary report on GAC-FBR operation to Southeastern Technology Center. August 28. Haselow Engineering, Aiken, SC.

Hobbie, J. E., Daley, R. J. and Jasper, S. 1977. Use of nucleopore filters for counting bacteria by fluorescence microscopy. Appl. Environ. Microbiol. 33:1225-1228.

Rodina. A.G. 1972. In: Methods in Aquatic Microbiology. (Eds. R.R. Colwell and M. S. Zambruski). pp. 240-244. University Park Press, Baltimore, MD. 


\section{Table 1.}

Total counts (AO), total heterotrophic aerobic bacteria (1\% PYTG plates) and petroleum degraders.

\begin{tabular}{llll}
\hline SAMPLE & $\begin{array}{l}\text { Total Counts } \\
\text { Cells/gdw or } \mathrm{ml}^{* *}\end{array}$ & $\begin{array}{l}\text { Heterotrophs } \\
\text { CFU/gdw or ml }\end{array}$ & $\begin{array}{l}\text { Petroleum Degraders } \\
\text { CFU/gdw or ml }\end{array}$ \\
\hline $13 \mathrm{FT}$ & $1.47 \mathrm{E}+08 \mathrm{Cells} / \mathrm{gdw}$ & $1.05 \mathrm{E}+08 \mathrm{CFU} / \mathrm{gdw}$ & $6.21 \mathrm{E}+07 \mathrm{CFU} / \mathrm{gdw}$ \\
$9 \mathrm{FT}$ & $4.53 \mathrm{E}+08 \mathrm{Cells} / \mathrm{gdw}$ & $1.16 \mathrm{E}+08 \mathrm{CFU} / \mathrm{gdw}$ & $3.14 \mathrm{E}+07 \mathrm{CFU} / \mathrm{gdw}$ \\
$5 \mathrm{FT}$ & $2.66 \mathrm{E}+08 \mathrm{Cells} / \mathrm{gdw}$ & $9.07 \mathrm{E}+07 \mathrm{CFU} / \mathrm{gdw}$ & $7.58 \mathrm{E}+07 \mathrm{CFU} / \mathrm{gdw}$ \\
Influent & $1.06 \mathrm{E}+06 \mathrm{Cells} / \mathrm{ml}$ & $3.40 \mathrm{E}+04 \mathrm{CFU} / \mathrm{ml}$ & $0.00 \mathrm{E}+00$ \\
Effluent & $9.18 \mathrm{E}+06 \mathrm{Cells} / \mathrm{ml}$ & $3.45 \mathrm{E}+04 \mathrm{CFU} / \mathrm{ml}$ & $0.00 \mathrm{E}+00$ \\
\hline
\end{tabular}

"gdw=grams dry weight

${ }^{* *} \mathrm{ml}=$ milliliter (groundwater) 


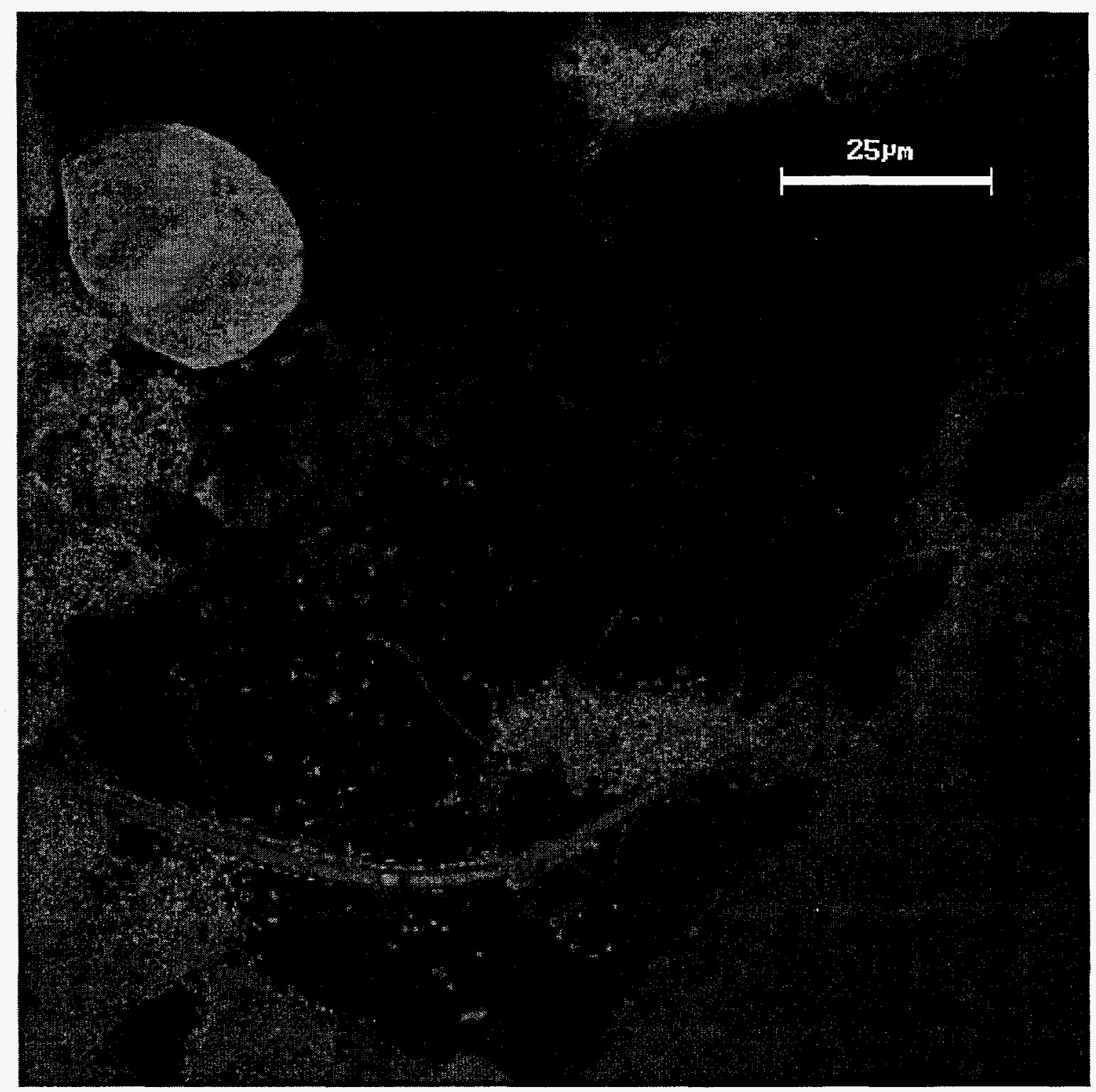

Figure 1. Biofilm from $5 \mathrm{ft}$ depth in GAC-FBR. 


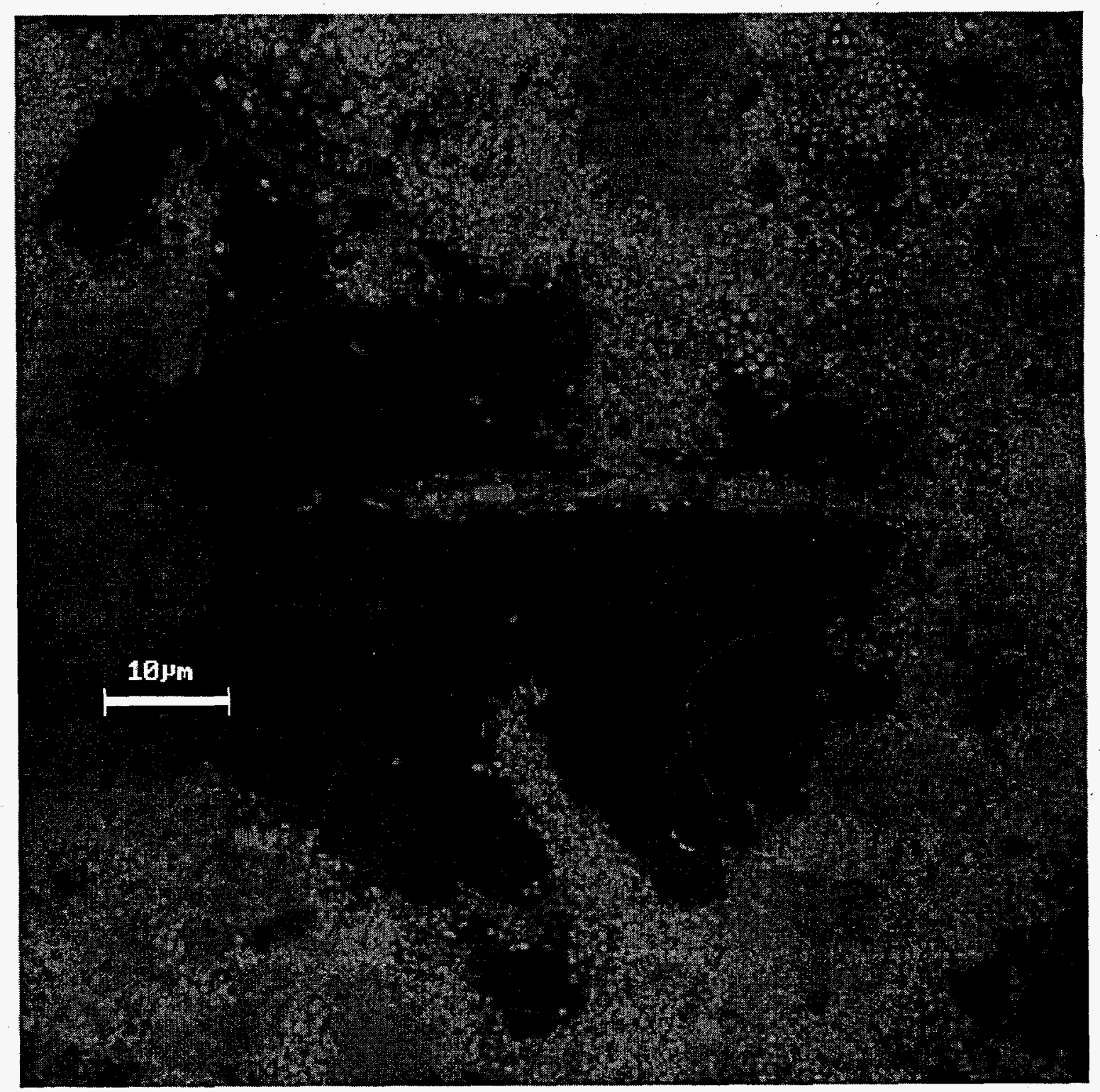

Figure 2. Biofilm from $9 \mathrm{ft}$ depth in GAC-FBR. 


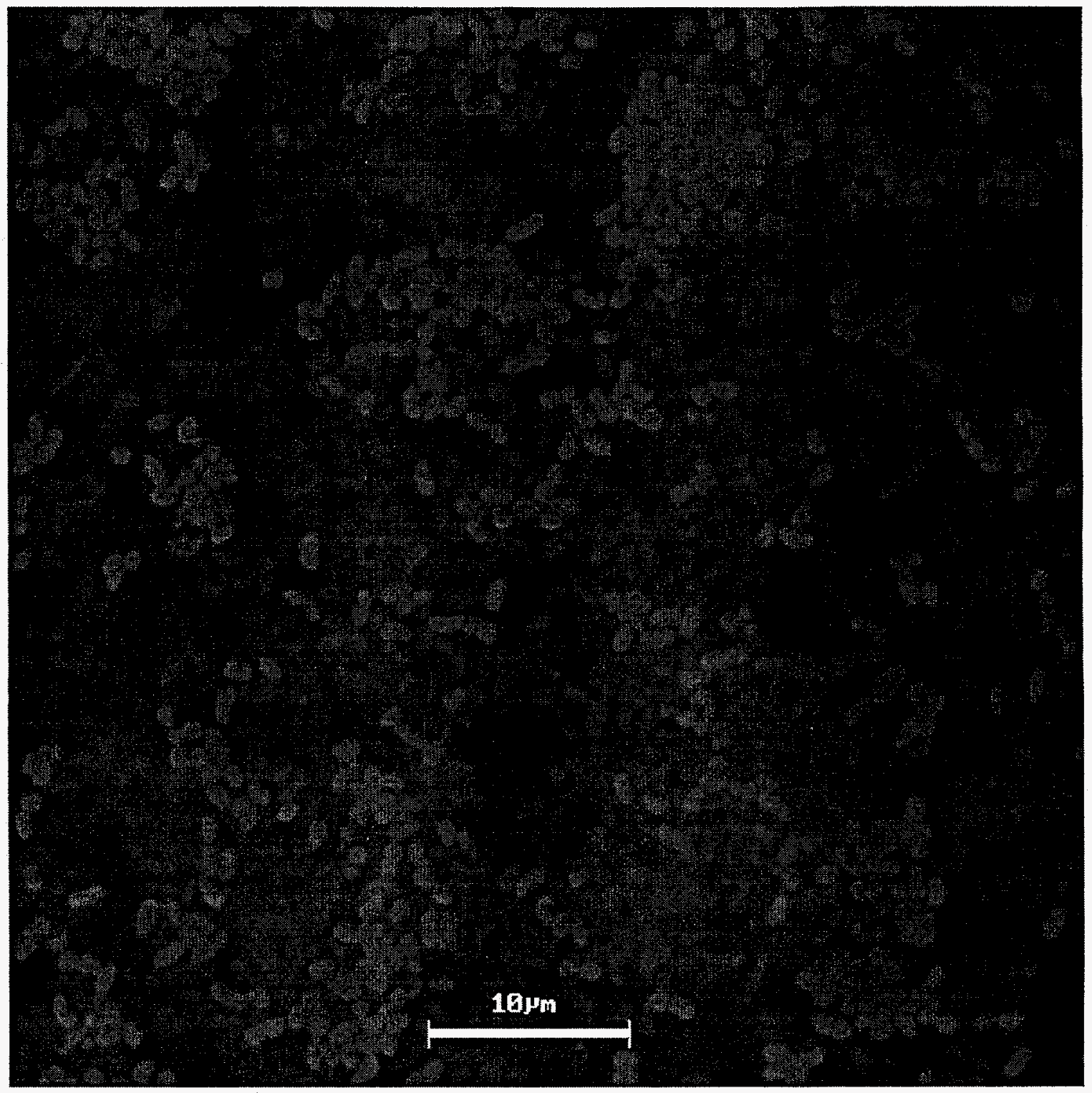

Figure 3. Biofilm from $13 \mathrm{ft}$ depth in GAC-FBR. 